\title{
The NPK1 mitogen-activated protein kinase kinase kinase is a regulator of cell-plate formation in plant cytokinesis
}

\author{
Ryuichi Nishihama, ${ }^{1,3,4}$ Masaki Ishikawa, ${ }^{1,4}$ Satoshi Araki, ${ }^{1,5}$ Takashi Soyano, ${ }^{1}$ Tetsuhiro Asada, ${ }^{2}$ \\ and Yasunori Machida ${ }^{1,6}$ \\ ${ }^{1}$ Division of Biological Science, Graduate School of Science, Nagoya University, Furo-cho, Chikusa-ku, Nagoya 464-8602, \\ Japan; ${ }^{2}$ Department of Biology, Graduate School of Science, Osaka University, Toyonaka 560-0043, Japan
}

\begin{abstract}
Mitogen-activated protein kinase (MAPK) cascades play important roles not only in the transduction of extracellular signals but in the progression of the cell cycle. However, evidence for their role in cytokinesis is limited. Here, we show that a tobacco MAPK kinase kinase (MAPKKK), designated NPK1, is required for cytokinesis. The activity of NPK1 increases in the late $M$ phase of the tobacco cell cycle. During expansion of a new cross-wall (cell plate) toward the cell cortex, NPK1 is consistently localized to the equatorial zone of the phragmoplast, the cytokinetic apparatus where the cell plate is formed. Expression of a kinase-negative mutant of NPK1 results in the generation of multinucleate cells with incomplete cell plates. Phragmoplasts can be formed, but its expansion toward the cell cortex is also blocked. Thus, our results indicate that the NPK1 MAPKKK is essential for the formation of the cell plate, especially for its lateral growth.
\end{abstract}

[Key Words: MAPKKK; NPK1 protein kinase; kinase-negative mutant; cell plate; phragmoplast; cytokinesis]

Received October 30, 2000; revised version accepted December 7, 2000.

Cytokinesis is the last essential step in distribution of genetic information to daughter cells and cytoplasmic partition. Compared with the earlier steps of cell cycle such as DNA replication and separation of chromosomes, the modes of cytokinesis have diverged depending on organisms (Field et al. 1999). In animal cells, cytokinesis is performed by constriction, that is by an outside-in mode. The contractile ring of actin and myosin anchored on the cell cortex is critical for the constriction. In contrast, cytokinesis in plant cells occurs in the reverse way (for review, see Gunning 1982; Staehelin and Hepler 1996; Heese et al. 1998; Smith 1999). At late anaphase, a plant-specific and complex array of microtubules (MTs) and microfilaments called the phragmoplast is formed at the spindle midzone in the center of the cell. Antiparallel MTs interdigitate at their plus ends in the equatorial zone of the phragmoplast. Fusion of Golgiderived vesicles that are proposed to be transported along the MTs toward this zone generates a membranous network, which eventually maturates into a new cross wall

\footnotetext{
${ }^{3}$ Present address: Department of Biology, University of Michigan, Ann Arbor, Michigan 48109-1048, USA.

${ }^{4}$ These authors contributed equally to this work.

${ }^{5}$ On leave from Central Research Institute, Ishihara Sangyo Kaisha, LTD., Kusatsu, Shiga 525-0025, Japan.

${ }^{6}$ Corresponding author.

E-MAIL yas@bio.nagoya-u.ac.jp; FAX 81-789-2966.

Article and publication are at www.genesdev.org/cgi/doi/10.1101/ $\operatorname{gad} .863701$
}

called the cell plate. The growth of the cell plate is accompanied with lateral expansion of the phragmoplast, which allows vesicle fusions to occur continuously at the peripheral region of the cell plate, resulting in the inside-out mode of cytokinesis.

These processes must involve a number of proteins for their execution and regulation. Many proteins have been found to be localized to the phragmoplast or the growing cell plate, including kinesin-like proteins (Liu et al. 1996; Asada et al. 1997; Bowser and Reddy 1997; Lee and Liu 2000), a dynamin-like GTPase (Gu and Verma 1996), a Cdc48 homolog (Feiler et al. 1995), a syntaxin (tSNARE) homolog (Lauber et al. 1997), an endo-1,4- $\beta-D-$ glucanase (cellulase) (Zuo et al. 2000), and mitogen-activated protein kinases (MAPKs; Calderini et al. 1998; Bögre et al. 1999). Of these, the KNOLLE syntaxin homolog and the KORRIGAN cellulase are essential for cytokinesis because mutations in either of their genes result in generation of incomplete cell walls and multinucleate cells (Lukowitz et al. 1996; Zuo et al. 2000).

In eukaryotes, MAPK signaling cascades play a central role in transduction of various extra- and intracellular stimuli and function in the control of developmental processes and the proliferation and death of cells (Robinson and Cobb 1997). The cascades typically consist of three protein kinases: a MAPK kinase kinase (MAPKKK), a MAPK kinase (MAPKK), and a MAPK (Garrington and Johnson 1999|. Signals transduced by components of the MAPK cascade influence various aspects of cell division, 
such as entry into the cell cycle (Pages et al. 1993), control of nucleotide biosynthesis (Graves et al. 2000), the G2/M phase transition (Wright et al. 1999), Golgi fragmentation at the $M$ phase in mammalian cells (Acharya et al. 1998), and the spindle assembly checkpoint (Minshull et al. 1994; Takenaka et al. 1998).

Recent results of localization of MAPKs in the spindle midzone and midbody in animal cells (Shapiro et al. 1998; Zecevic et al. 1998/ and in the phragmoplast in plant cells (Calderini et al. 1998; Bögre et al. 1999) suggest roles for MAPKs in cytokinesis. However, the available data are related exclusively to the subcellular localization of MAPKs and their activation patterns, and so our understanding of the role of the MAPK pathway in cytokinesis is still incomplete.

The NPK1 gene from tobacco encodes a member of the MAPKKK family, and the kinase domain of NPK1 can replace the functions of several yeast MAPKKKs (Banno et al. 1993; Nishihama and Machida 2000). NPK1 and its Arabidopsis orthologous genes, $A N P 1 / 2 / 3$, are transcribed in proliferating and division-competent cells or in organs rich in these cells, an observation that suggests their role in cell division (Banno et al. 1993; Nishihama et al. 1997; Nakashima et al. 1998). Recently, it was reported that overexpression of the kinase domain of NPK1 or ANP1 in maize or Arabidopsis cells results in suppression of auxin-induced gene expression and in activation of stress signaling (Kovtun et al. 1998, 2000). Here, we report biochemical and immunochemical analyses of intrinsic NPK1 during cell cycle and effects of expression of kinase-negative NPK1 on the progression of the cell cycle. The results show that NPK1 MAPKKK regulates a critical step in the lateral growth of the cell plate. Thus, the present work elucidates the novel part played by a member of MAPKKKs.

\section{Results}

NPK1 protein is the most abundant, phosphorylated, and activated in $M$ phase

Anti-NPK1 antibodies were raised against a synthetic oligopeptide that corresponds to amino acid residues 557 to 574 of NPK1 (Fig. 1A). The antibodies recognized a single protein with $\sim 80 \mathrm{kD}$ (corresponding to the estimated molecular mass of NPK1) in protein extracts prepared from tobacco BY-2 cells at logarithmic phase but not in extracts from cells at stationary phase (Fig. 1B), consistent with mRNA analysis (Banno et al. 1993).

Cell cycle of BY-2 cells was synchronized with aphidicolin from the $\mathrm{G}_{1} / \mathrm{S}$ boundary. NPK1 accumulated immediately after washing the drug (time 0 in Fig. 1C), its amount increased toward $M$ phase $(8$ to $10 \mathrm{~h})$ and decreased after that phase (12 to $14 \mathrm{~h})$. In the $\mathrm{M}$ phase, signals of NPK1 were broad, suggesting an occurrence of some modification in the NPK1 protein. To more precisely examine the behavior of NPK1 during $M$ phase, the cell cycle that had been synchronized with aphidicolin was arrested at prometaphase using propyzamide, a
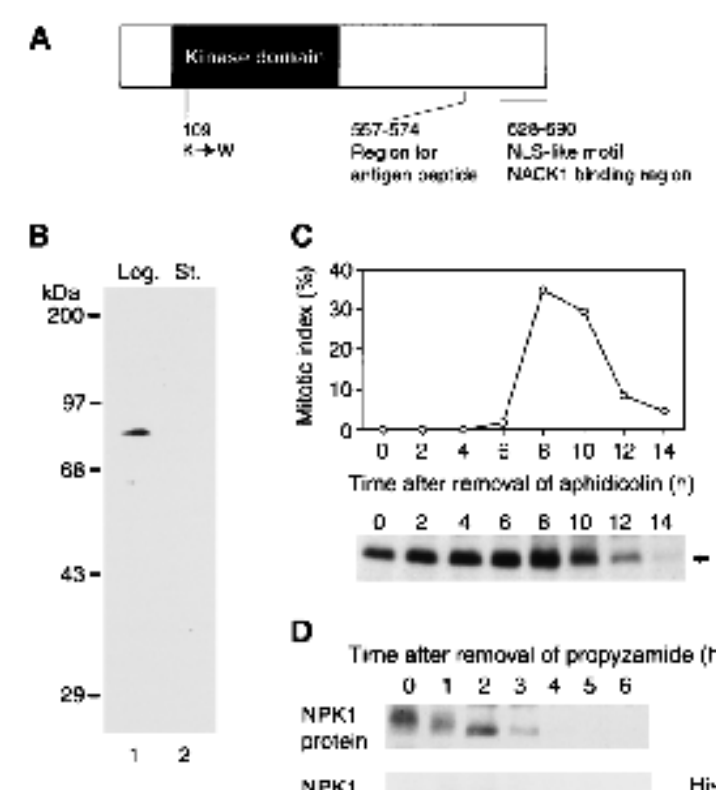

C
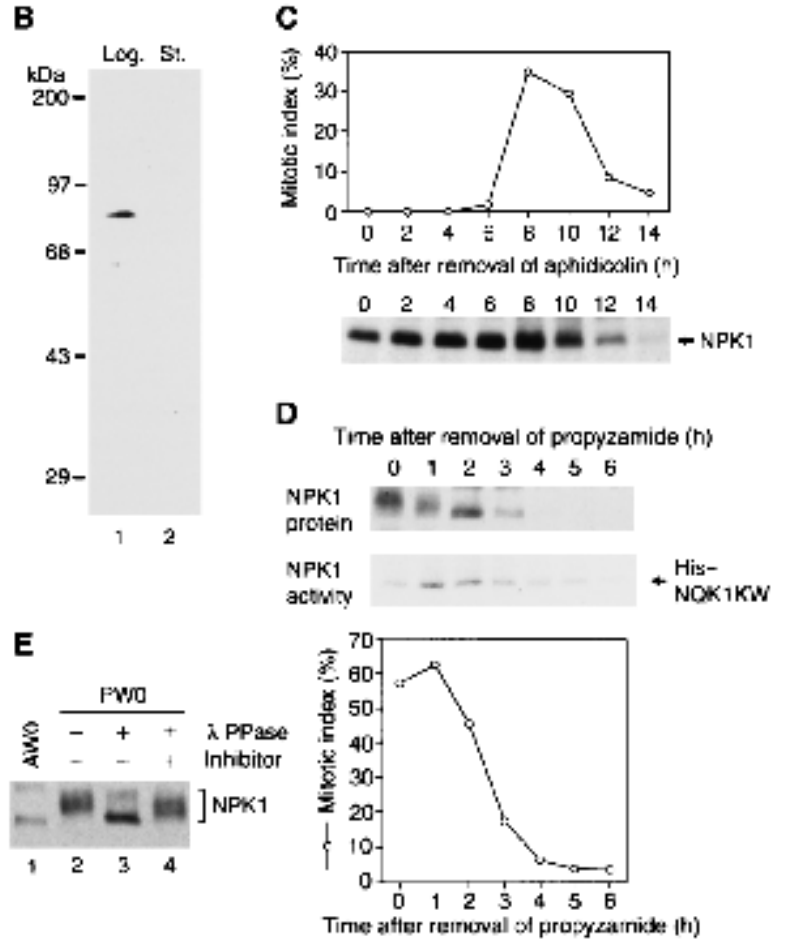

Figure 1. The accumulation and the activity of NPK1 during the cell cycle in tobacco BY-2 cells. (A) Domain organization and critical regions in the NPK1 protein. See details in the text. (B) Recognition specificity of anti-NPK1 antibodies. Protein extracts from BY-2 cells in a logarithmic (lane 1) or stationary (lane 2) phase were analyzed by Western blot using anti-NPK1 antibodies (P557-2). (C) Accumulation of NPK1 during the cell cycle of the BY-2 cells. The cell cycle was arrested at the $G_{1} / S$ boundary by the aphidicolin treatment. At the indicated times (hours) after the removal of aphidicolin, cells were harvested and proteins were extracted. (Top) A plot of mitotic indices, (bottom) Western blot with the anti-NPK1 antibodies. (D) Accumulation and activity of NPK1 during M phase. The cell cycle was arrested at prometaphase by the propyzamide treatment after the release from the aphidicolin block. At the indicated times (hours) after the removal of propyzamide, cells were harvested and proteins were extracted. (Top) Western blot of NPK1; (middle) Kinase activities of NPK1 determined by the immunocomplex kinase assay with recombinant histidine-tagged kinase-negative NQK1 (HisNQK1KW) as substrate. NQK1 is a novel tobacco MAPKK downstream from NPK1 (see the text); (bottom) A plot of mitotic indices. $(E)$ Mobility shift of NPK1 proteins by treatment with $\lambda$ protein phosphatase. Proteins in the extract prepared from BY-2 cells at time 0 in panel $D$ (PWO) were incubated with the reaction buffer (lane 2), with $\lambda$ protein phosphatase (lane 3), or with the phosphatase plus its inhibitor (1 mM sodium $O$-vanadate) (lane 4) at $37^{\circ} \mathrm{C}$ for $1 \mathrm{~h}$. NPK1 proteins in these reaction mixtures as well as in the extract from cells just after the release from the aphidicolin block (Lane 1, AW0) were detected by Western blot analysis using the anti-NPK1 antibodies. 
MT-depolymerizing drug, and then released by washing the drug. At the prometaphase (time 0 in Fig. 1D), NPK1 was detected as broad bands whose mobilities were greatly retarded. As the cell cycle progressed, the NPK1 bands shifted down whereas the mitotic index (MI) was still high ( $2 \mathrm{~h}$ in Fig. 1D), and the amount of NPK1 diminished to the limit of detection with the rapid decrease in MI (3 to $4 \mathrm{~h}$ ). These data suggest that NPK1 undergoes modification at early $M$ phase that is reversed at late $M$ phase, followed by probable protein degradation.

Using $\lambda$ protein phosphatase, we examined whether the mobility retardation of NPK1 would be caused by phosphorylation. As shown in Figure 1E, the treatment of the prometaphase-cell extract that contained the low mobility NPK1 (lane 2) with the phosphatase resulted in shifts of the NPK1 bands down (lane 3 ) to the same position as the NPK1 proteins from the $G_{1} / S$ boundary (lanes 1), but the treatment in the presence of the phosphatase inhibitor did not (lane 4). These results suggest that NPK1 is extensively phosphorylated at prometaphase.

To examine the activity of NPK1 during M phase, we performed an immunocomplex kinase assay using a histidine-tagged recombinant protein of a kinase-negative mutant of a MAPKK (named His-NQK1KW) as a substrate protein, which has recently been identified as a putative downstream factor of NPK1 in our laboratory (T. Soyano et al., unpubl.). The activity of NPK1 was increased transiently 1 to $2 \mathrm{~h}$ after the removal of propyzamide, at a time that corresponded to the late $M$ phase (Fig. 1D).

\section{Distribution of NPK1 is dynamic during $M$ phase}

Next, we examined subcellular localization of NPK1 in BY-2 cells at the M phase (Fig. 2). Cells cultured for $8 \mathrm{~h}$ after the release from the aphidicolin block were fixed and triple-stained with the antibodies against NPK1, antibodies against $\alpha$-tubulin, and 4',6-diamidino-2-phenylindole (DAPI). In cells containing a nucleus with condensing chromosomes and a preprophase band of MTs, NPK1 was detected within the nucleus (Fig. 2A, prophase). From prometaphase to metaphase, immunoreactive NPK1 was dispersed in the cytoplasm in patches (Fig. 2A, metaphase; data not shown for prometaphase). When the anti-NPK1 antibodies had been incubated with the antigenic oligopeptide from NPK1 before use, no patches were detected (Fig. 2B, metaphase). At anaphase, signals caused by NPK1 were widely distributed around the spindle midzone between the two sets of chromosomes (Fig. 2A). When cells at early telophase began to form a phragmoplast, NPK1 was localized on the equatorial plain of the phragmoplast (Fig. 2A).

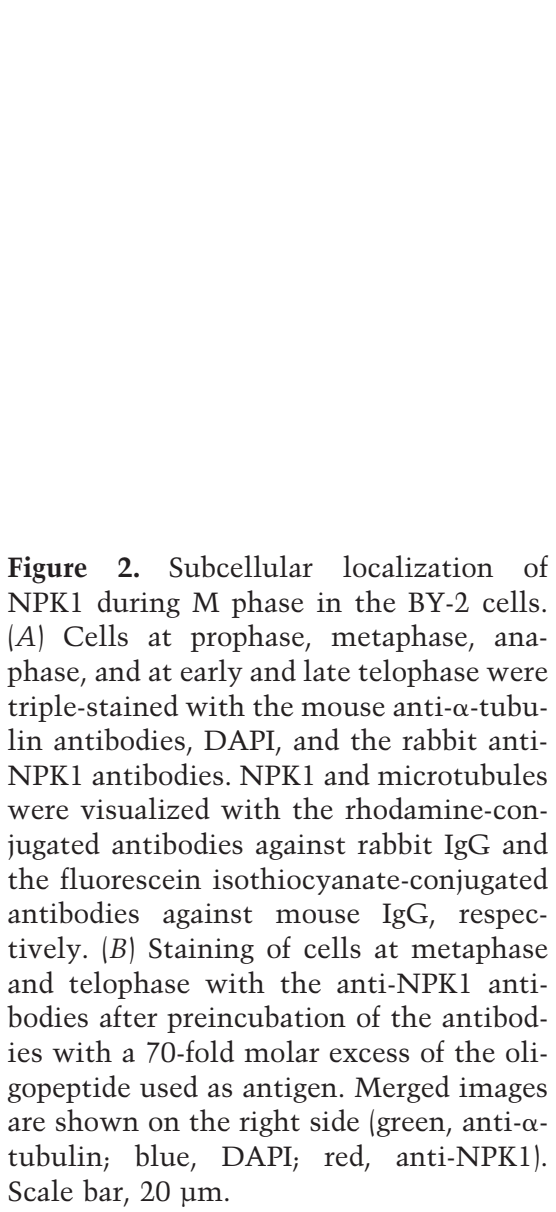

A

Prophase

Metaphase

Anaphase

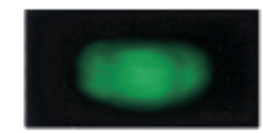

Early
telophase

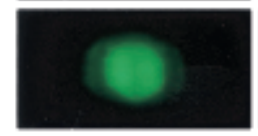

Late

telophase
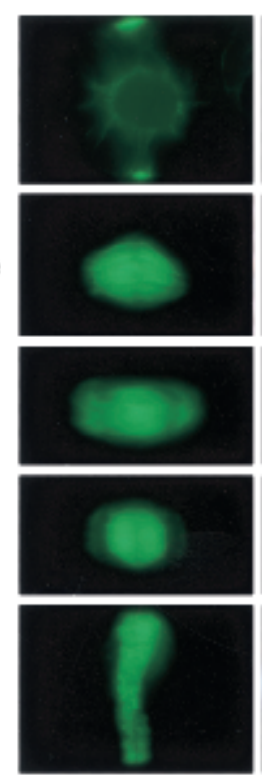

西
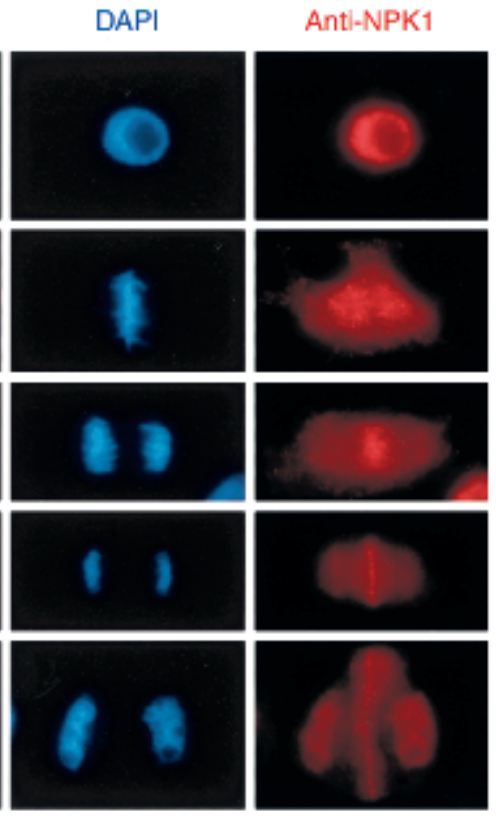

B
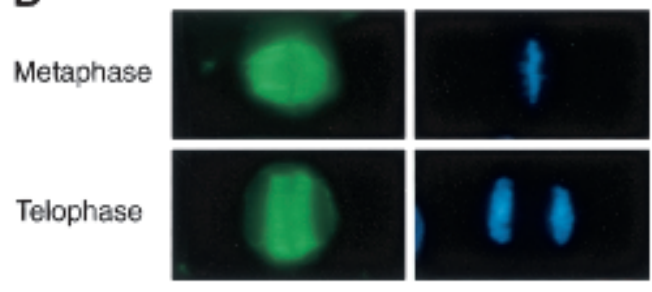

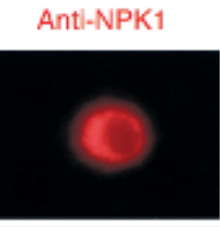

Merged
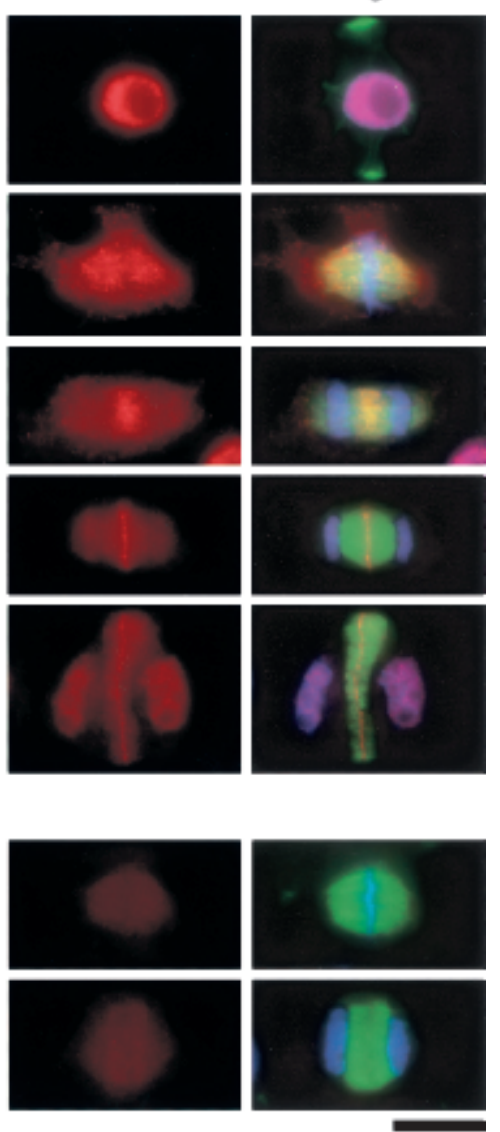
The antibodies against NPK1 that had been preincubated with the above-mentioned oligopeptide did not stain this region (Fig. 2B, telophase). During expansion of the phragmoplast from early to late telophase, the signal caused by NPK1 was consistently detected in the MTinterdigitating region of the ring-shaped and mature phragmoplast (Fig. 2A, also see Fig. 6). NPK1 was also redistributed to the newly forming daughter nuclei.

\section{Expression of kinase-negative NPK1 causes multinucleate cells}

We have recently shown that NPK1 could be activated through the molecular association of its carboxyl-terminal regulatory region (see Fig. 1A) with a newly identified member of the family of kinesin-like MT-based motor protein, NACK1 (R. Nishihama et al., in prep.). We speculate that the localization of NPK1 to the center of the phragmoplast might be achieved by association with the NACK1 kinesin-like protein. Thus, to address an in vivo role of NPK1, we adopted a dominant-inhibitory strategy using a kinase-negative mutant of NPK1 because, as in the case of kinase-negative mutants of other MAPKKKs (Posas and Saito 1998; Takekawa and Saito 1998; Sakurai et al. 1999|, we anticipated that overexpression of the mutant NPK1 might interfere with the proper association of endogenous NPK1 with NACK1, with potential resultant inhibition of the NPK1-mediated signaling pathway. We made a mutant cDNA construct that encoded a hemagglutinin (HA)-epitope-tagged and kinase-negative NPK1, designated HA-NPK1KW, with an amino-acid substitution from lysine to tryptophan in the ATP-binding region (see Fig. 1A). We ma- nipulated this cDNA derivative such that its expression could be regulated by the dexamethasone-inducible (DEX-inducible) transcription system (Aoyama and Chua 1997), and then we introduced it into BY-2 cells. We selected three cell lines (HA-KW cell lines) that grew normally without DEX but synthesized HA-NPK1KW in the presence of DEX (maximum levels were obtained 18 to $24 \mathrm{~h}$ after addition of 0.1 to $1.0 \mu \mathrm{M}$ DEX) but not in the absence of DEX. We also generated transgenic cell lines with DEX-inducible HA-tagged wild-type NPK1 (HANPK1) and control cell lines that had been transformed with the empty vector (Vec cell lines).

Portions of the various cell cultures at stationary phase were transferred to 20 volumes of fresh medium prepared with or without $0.1 \mu \mathrm{M}$ DEX. Cells were stained with orcein 1, 2, and $3 \mathrm{~d}$ after subculture (DAS). In one of the Vec cell lines, Vec1, regardless of the presence or absence of DEX, all cells at interphase had single nuclei (Figs. 3A,B). In contrast, in a HA-KW cell line, HA-KW23, a significant proportion of cells was binucleate or multinucleate and unusually large in the presence of DEX (Fig. 3D, an example of an octanucleate cell). One DAS, $\sim 8 \%$ of cells was binucleate (Fig. 3E). Two and three DAS, cells with four and eight nuclei appeared, respectively (Fig. 3E). Cells that had nuclei with numbers other than 2,4 , and 8 or malformed nuclei also appeared but at low frequencies (Fig. 3E). Without DEX, practically all HA-KW23 cells at interphase had single nuclei (Fig. 3C). Thus, it appeared that the HA-NPK1KW expression inhibited cytokinesis but allowed nuclear divisions to occur. We obtained slightly elevated frequencies of the multinucleate cell formation when DEX was added up to $10 \mu \mathrm{M}$, whereas the frequency reduced when
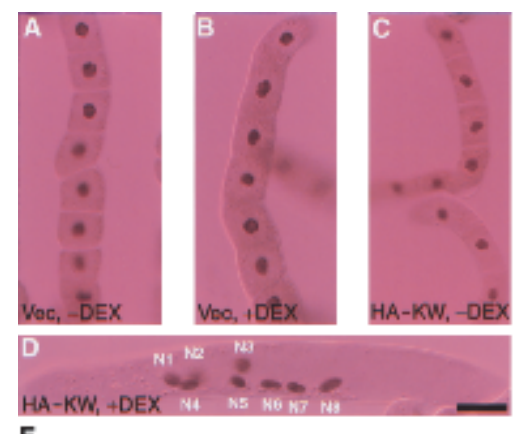

E

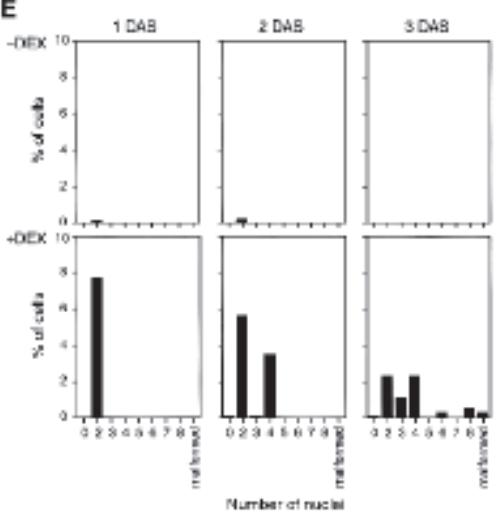

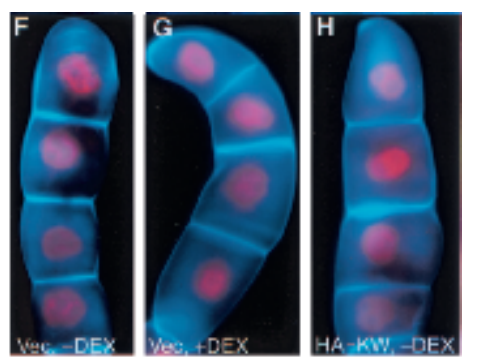
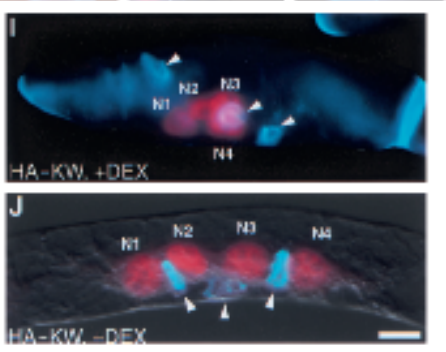

Figure 3. Generation of multinucleate cells by expression of the kinase-negative NPK1. Vec1 cells transformed with the empty vector $(A, B, F, G)$ and HAKW23 cells transformed with the HA-NPK1KW-expressing vector $(C, D, H-J)$ were subcultured in the presence of $0.1 \mu \mathrm{M} \operatorname{DEX}(-\mathrm{DEX} ; B, D, G, I, J)$ or in the absence of DEX (-DEX; $A, C, F, H$ ). Three days after the start of culture, cells were stained with orcein $(A-D)$, calcofluor (blue) and PI (red) (F-I), or aniline blue (blue) and PI (red) $(J)$. Images after double staining were merged in panels $(F-J)$. A Normarski image (gray) was also merged in panel $(J)$. Arrowheads indicate incomplete cell plates. N1 through N8 in panels $(D, I, J)$ indicate the nuclei found in individual cells. (E) Time course of frequencies of multinucleate-cell formation. By orcein staining, populations of HA-KW23 cells with the indicated numbers of nuclei or malformed nuclei were examined 1,2 , and $3 \underline{\mathrm{d}}$ after onset of subculture (DAS) without DEX (top) or with $0.1 \mu \mathrm{M}$ DEX (bottom). The population of cells with one nucleus is not shown. More than 1,000 cells were examined. Scale bar in $D, 50 \mu \mathrm{m}$ for $A-D$; bar in $J, 20 \mu \mathrm{m}$ for $F-J$. 
the concentration of DEX decreased to $0.01 \mu \mathrm{M}$ or lower (data not shown). Other HA-KW and Vec cell lines gave results similar to those of HA-KW23 and Vec1 lines, respectively, and HA-NPK1-expressing cell lines yielded no multinucleate cells (data not shown).

Multinucleate phenotype is observed in cells expressing the kinase-negative NPK1 but not in those expressing wild-type NPK1

We performed similar experiments with green fluorescent protein-fused (GFP-fused) NPK1KW (GFP::NPK1KW) and NPK1 (GFP::NPK1) constructs to investigate more precisely the correlation between expression of NPK1KW and phenotype. We generated several transformed BY-2 cell lines that could induce expression of GFP::NPK1KW, GFP::NPK1, and GFP itself in response to DEX (designated G-KW, G-WT, and GFP cell lines, respectively). These cell lines produced detectable amounts of GFP-fused proteins or GFP protein at $2 \mathrm{~h}$ and maximum amounts at $24 \mathrm{~h}$ after the addition of $0.1 \mu \mathrm{M}$ DEX (data not shown). GFP::NPK1 and GFP::NPK1KW were genetically functional and nonfunctional as a MAPKKK in yeast cells, respectively (data not shown).

When GFP::NPK1KW was expressed by $0.1 \mu \mathrm{M}$ DEX, multinucleate cells were found in all the G-KW lines (Fig. 4A). Frequencies of appearance of such cells were
$6 \%-13 \%$ and $13 \%-20 \%$ one and three DAS, respectively (Fig. 4B).

Under these conditions, $15 \%-30 \%$ of cells was GFP positive depending on the cell lines (data not shown). Therefore, more than half of the cells that were GFP positive showed the multinucleate phenotype. The remaining half did not show a clear phenotype although they were GFP positive. This might have been because of incomplete inhibition by NPK1KW, because the extent of inhibition might depend on a balance between endogenous NPK1 and exogenous NPK1KW. Without DEX, frequencies of multinucleate cells were very low (one DAS of Fig. 4B; lower than $0.5 \%$ ). On the other hand, two cell lines (12 and 18) that expressed the GFP-fused wildtype NPK1 (G-WT) showed only low frequencies of appearance of multinucleate cells in the presence of DEX (three DAS of Fig. 4B; lower than 1.5\%). None of the cell lines that expressed GFP alone did not show such an abnormal phenotype even in the presence of DEX (Fig. 4B). Taken together, formation of multinucleate cells is concluded to be caused by the expression of the kinasenegative NPK1.

Expression of the kinase-negative NPK1 affects guard cell development in transgenic tobacco plants

We also observed multinucleate cells in transgenic tobacco plants that harbored DEX-inducible HA-NPK1KW
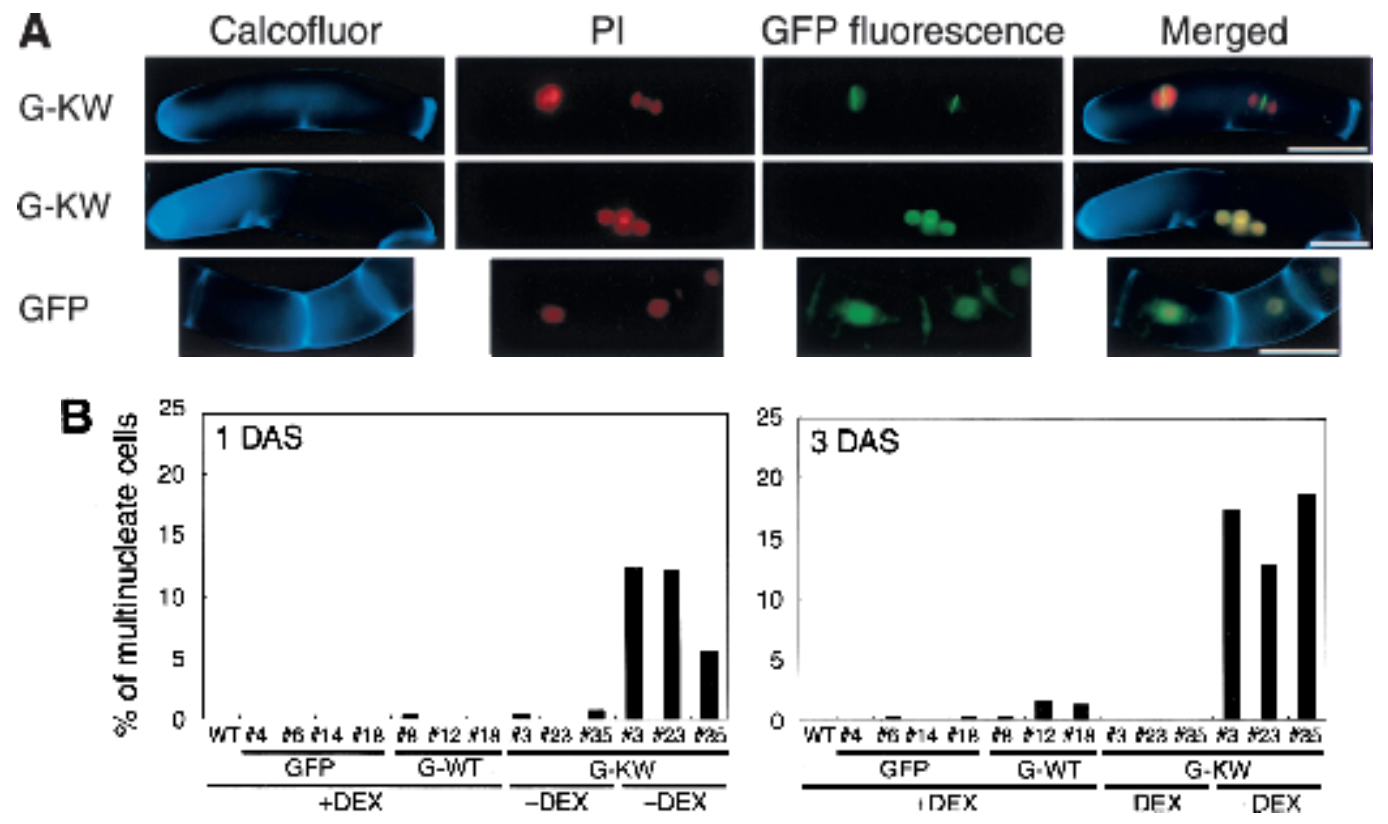

Figure 4. Effects of expression of GFP::NPK1KW, GFP::NPK1, and GFP on multinucleate-cell formation. $(A)$ Formation of multinucleate cells induced by expression of GFP::NPK1KW. Cells of G-KW3 (top and middle) and GFP4 (bottom) cell lines transformed with the GFP::NPK1KW- and GFP-expressing vector, respectively, were cultured with $0.1 \mu \mathrm{M}$ DEX. Three DAS, cells were stained with calcofluor (blue) and PI (red), respectively. Fluorescence from these stainings and fluorescence caused byGFP (green) are visualized. Merged images are also shown. Two different types of G-KW3 multinucleate cells (a telophase cell in which two telophase events underwent [top] and a tetranucleate interphase cell [middle]) are shown. Scale bar, $50 \mu \mathrm{m}$. (B) Frequencies of formation of multinucleate cells in several independent lines from the nontransformant (WT), GFP, G-WT, and G-KW cell lines. Cells of each line were cultured with $(+)$ or without $(-) 0.1 \mu \mathrm{M}$ DEX. Proportions of multinucleate cells were measured one and three DAS by orcein staining. 
(HA-KW plant lines). On germination on a DEX-containing medium, cotyledons of HA-KW plant lines developed with rough surfaces (Fig. 5D). The stomata of cotyledons consistently contained the most severely affected cells: many guard cells were binucleate; some had no nucleus; and cytokinesis in some cells was incomplete or absent (Fig. 5H-K). These phenotypes can be explained by arrest or delay of cytokinesis during the development of guard cells but the occurrence of nuclear division. Significant numbers of epidermal cells from the same plants were also multinucleate (Fig. 5L). In many aberrant guard cells, two daughter nuclei were incompletely separated after division (Fig. 5H-K). Such closely apposed nuclei were also observed in the HA-KW derivatives of BY-2 cells (see Fig. 3I,J). Again, these abnormalities were not visible in any lines of HA-NPK1-expressing plants (data not shown).

\section{Expression of the kinase-negative NPK1 induces generation of incomplete cell plates}

All the multinucleate cells that were induced by HANPK1KW had aberrant cell walls. Staining with calcofluor, which detects $\beta$-glucans in cell walls, or with aniline blue, which detects callose that accumulates exclusively in newly synthesized cell plates, revealed disc- or stublike structures in multinucleate cells from all HAKW cell lines (Fig. 3I,J) and all G-KW cell lines (Fig. 4A). In DEX-treated Vec and GFP cells (Figs. 3G,4A) and in DEX-untreated cells (Fig. 3F,H), no such structures were observed. Hence, NPK1KW might not have inhibited an initial step in the formation of the cell plate but might, rather, affect its growth.

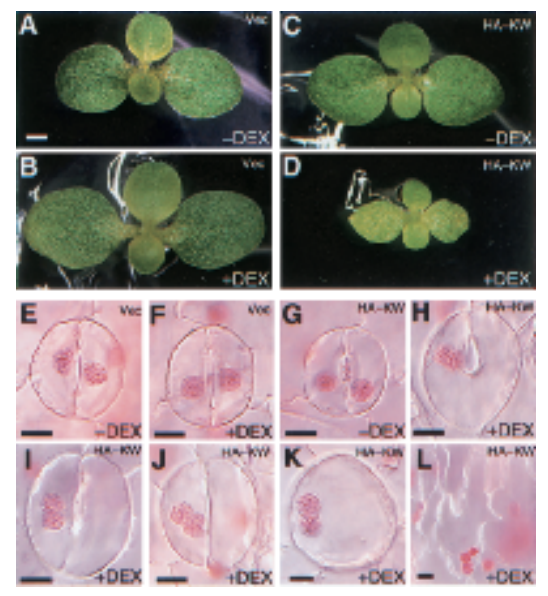

Figure 5. Generation of multinucleate cells in the epidermis of cotyledons by expression of the kinase-negative NPK1. Seeds of the empty vector-transformed tobacco plant $(A, B, E, F)$ and the DEX-inducible HA-NPK1KW construct-transformed plant $(C, D, G-L)$ were germinated on solid media supplemented with $1 \mu \mathrm{MDEX}(B, D, F, H-L)$ or without $\operatorname{DEX}(A, C, E, G) .(A-D)$ Surface views of cotyledons of 10-day-old seedlings. $(E-K)$ Normarski images of orcein-stained guard cells in cotyledons. $(L)$ A Normarski image of orcein-stained pavement cells in cotyledons. Scale bar in $A, 1 \mathrm{~mm}$ for $A-D$, and bars in $E-L, 10 \mu \mathrm{m}$.
Assembly of the phragmoplast is initiated before the cell-plate formation. We next examined whether phragmoplast could be formed in NPK1KW-expressing cells. Telophase cells from the G-WT and G-KW cell lines that had been cultured in the presence of DEX were double-stained with the antibodies against $\alpha$-tubulin and DAPI. Phragmoplasts were normally stained with the antibodies against $\alpha$-tubulin in GFP-positive cells from both mutant and wild-type lines, and the signals caused by the fluorescence of GFP were detected in the equatorial zones of the phragmoplasts (Fig. 6A). Thus, NPK1KW did not inhibit the phragmoplast assembly.

\section{Inhibition of phragmoplast expansion in living cells expressing the kinase-negative NPK1}

To examine whether the expansion of phragmoplast was also affected, we further analyzed signals caused by the fluorescence of GFP on phragmoplasts in living G-WT and G-KW cells. Among synchronized cells of these lines at $M$ phase, we selected cells that emitted the smallest width of fluorescent signals caused by GFP that might reflect the phragmoplast at an initial stage of development because lengths of phragmoplasts in the equatorial direction were roughly equal to those of bands of NPK1 or of signals caused by GFP (see Figs. 2B and $6 \mathrm{~A})$. From the time of selection (time 0), images caused by fluorescence of GFP from single cells were recorded at 10-min intervals (Fig. 6B). In G-WT cells, the fluorescent signal extended toward the periphery of the cell during the first $30 \mathrm{~min}$ and reached a plateau value (Fig. 6C). The fluorescent signal was finally recorded as a ring-like structure (Fig. 6B, upper panel). In contrast, the fluorescent signal in G-KW cells barely expanded at all (Fig. 6B, lower panel, and C). When the ratio of the length of the recorded fluorescent signal to the width of the cell (average widths of G-WT and G-KW cells were $39 \mu \mathrm{m}$ and $36 \mu \mathrm{m}$, respectively) was calculated, it was clear that the fluorescent signals in $\mathrm{G}-\mathrm{KW}$ cells did not extended as far as the periphery of the cells (Fig. 6D). Such expansion arrest was found in a half of GFP positive cells and expansion occurred in the remaining half, which might have been caused by incomplete inhibition by NPK1KW as described above (Fig. 4). This time-lapse analysis to observe behavior of GFP fluorescence in living cells showed directly that phragmoplast-localized GFP::NPK1KW inhibited lateral expansion of the phragmoplast.

\section{Discussion}

The results in the present study have provided four lines of evidence for involvement of the NPK1 MAPKKK in cell-plate formation: (1) the activity of NPK1 increased during the late M phase (Fig. 1); (2) NPK1 was localized to the equatorial zone of the expanding phragmoplast (Fig. 2); (3) expression of the kinase-negative mutant of NPK1 (NPK1KW) resulted in the generation of multinucleate cells with aberrant cell plates (Figs. 3-5); and (4) 
Figure 6. Inhibition of lateral expansion of phragmoplast by the kinase-negative NPK1. Cell cycles of BY-2 cells that had been transformed with DEX-inducible GFP::NPK1 (G-WT8) or GFP::NPK1KW (G-KW3) construct were synchronized with aphidicolin. DEX $(0.1$ $\mu \mathrm{M})$ was added to cultures $12 \mathrm{~h}$ after the addition of aphidicolin and cells were cultured for further $12 \mathrm{~h}$. After removal of aphidicolin, cells were cultured for 10 $\mathrm{h}$ in the presence of $0.1 \mu \mathrm{M}$ DEX. (A) Visualization of phragmoplasts and nuclei at telophase cells expressing GFP fusion proteins. Cells were fixed and doublestained with the $\alpha$-tubulin-specific antibodies (red) and DAPI (blue). Fluorescence from such staining and fluorescence caused by GFP (green) are visualized with merged. $(B-D)$ Transitions of GFP-fluorescence patterns in living G-WT 8 (top) and G-KW3 (bottom) cells. (B) Aliquots of cell cultures prepared as described above were put on slides. Photographs of fluorescence and Normarski images of single cells were taken at 10-min interval. (C) A plot for lengths ( $\mu \mathrm{m})$ of GFP fluorescence signals against time (minutes). (D) A plot for ratios of lengths of GFP signals to cell widths against time (minutes). Scale bar in $A, 20 \mu \mathrm{m} ; B, 40 \mu \mathrm{m}$.
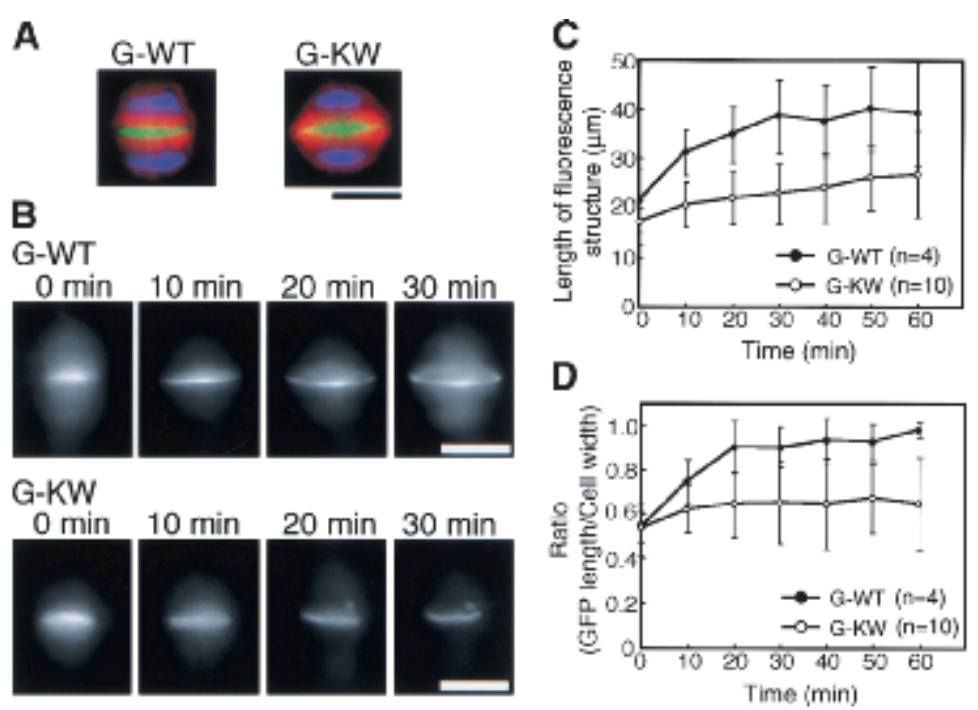

phragmoplasts to which the mutant NPK1 had been localized ceased from expanding toward the cell cortex (Fig. 6). Although the mechanism by which the phenotypes are generated has yet to be examined, NPK1KW may have had an inhibitory influence on the NPK1-mediated signal pathway for the following reasons. As MAPKKKs can be activated by molecular interaction with corresponding activator proteins (Posas and Saito 1998; Takekawa and Saito 1998; Sakurai et al. 2000), it has been shown recently that NPK1 was also activated by interaction with NACK1, which is a novel member of the kinesin-like protein family and accumulated at late $M$ phase (Nishihama et al., unpubl.). In addition, NPK1 and NACK1 proteins were consistently colocalized to the equatorial zone of phragmoplast from anaphase to late telophase (Figs. 2-6; Nishihama et al., unpubl.). Therefore, if an excess amount of NPK1KW proteins are produced in the plant cells, they may act as competitive inhibitors against the activation of NPK1 by NACK1. The underlying mechanism of the phenotypes should be further investigated by fine biochemical and cell-biological analyses.

Recently, the DEX-inducible gene expression system used in this study was reported to cause the growthdefect phenotype by the artificial GVG transcription factor in some transgenic Arabidopsis plants (Kang et al. 1999).

Our control experiments using wild-type NPK1, GFP alone, or empty vector clearly showed that multinucleate cells are generated by the expression of NPK1KW. Furthermore, Northern blot analysis showed that the GVG mRNA levels in NPK1KW-expressing BY-2 cells or tobacco plants were less than or equal to those in control lines (data not shown). It is, however, still difficult to completely rule out the possibility that the multinucleate phenotype might be caused by a combinatorial effect of expression of both NPK1KW and GVG. Nevertheless, the pattern of activation and subcellular localization of
NPK1 coincide well with the phenotypes of cells expressing NPK1KW. Therefore, all the data presented here show that NPK1 functions in the cell-plate formation during cytokinesis.

\section{NPK1 signaling}

In addition to the activation mechanism, our biochemical analysis suggests a repression mechanism of the NPK1 activity. In prometaphase-arrested cells, only low activity of NPK1 was detected although the NPK1 protein accumulated at a high level (Fig. 1D). Treatment of the NPK1 protein from prometaphase with protein phosphatase caused shift down of the relative mobility of the NPK1 protein during SDSPAGE (Fig. 1E), showing that NPK1 is extensively phosphorylated in those cells. Changes in degrees of the phosphorylation were negatively correlated with those in the activity from prometaphase to late $\mathrm{M}$ phase (Fig. 1D).

Thus, hyperphosphorylation on NPK1 might be related to its low activity. Candidate kinases for this hyperphosphorylation might be cyclin-dependent protein kinases (CDKs), because plant CDKs have been shown to be active in early mitosis and to be inactivated around metaphase in M phase (Mironov et al. 1999). Consistent with this idea, NPK1 has possible sites of phosphorylation by CDKs in the regulatory domain (Nishihama et al. 1997), and our preliminary data showed that NPK1 was phosphorylated by a starfish CDK (data not shown).

We have also identified new types of MAPKK and MAPK (tentatively designated NQK1 and NRK1, respectively) that appear to function downstream from NPK1 using yeast systems (Soyano et al., unpubl.). NQK1 is supposed to act downstream from NPK1 because NPK1 phosphorylated NQK1 in vitro (Fig. 1D). We currently investigate whether these proteins are genuine downstream factors of NPK1 in vivo. The MAPKs, $443^{\mathrm{Ntt6}}$ from tobacco and MMK3 from alfalfa, are also candidate 
MAPKs that might act downstream from NPK1 in respective plants because their subcellular localization and activation profiles are similar to those of NPK1 (Calderini et al. 1998; Bögre et al. 1999). However, recent studies indicate that MAPKKKs can also activate MAPKK-unrelated protein kinases (Lee et al. 1997; Ninomiya-Tsuji et al. 1999), so it is possible that NPK1 might control cytokinesis via some other factor.

\section{The role of NPK1 in cell-plate formation}

Microscopic observations in combination with treatments of various drugs have elucidated the mechanistic features of plant cytokinesis (for review, see Staehelin and Hepler 1996; Heese et al. 1998). Expansion of the cell plate involves three mutually dependent processes (Heese et al. 1998): (1) transport of Golgi-derived vesicles along phragmoplast MTs; (2) fusion of the vesicles in MT-interdigitating regions; and (3) outward redistribution of phragmoplast MTs. The expansion of both the phragmoplast and the cell plate is inhibited by taxol (Yasuhara et al. 1993), a drug that affects the stabilization of MTs, and it has been proposed that MTs are depolymerized at the inner side of the phragmoplast and tubulins are repolymerized at its outer side. Brefeldin A, which blocks the supply of Golgi-derived vesicles by disrupting the Golgi apparatus, also inhibits lateral expansion of phragmoplast and cell plate (Yasuhara and Shibaoka 2000). Vesicle fusion is essential for cell-plate expansion because mutations in the KNOLLE gene that encodes a homolog of syntaxin, which is involved in vesicle fusion in animal systems, impairs vesicle fusion, and results in incomplete cell walls (Lukowitz et al. 1996). Thus, inhibition of any of the three processes impedes the expansion of the cell plate.

The ring-shaped distribution of NPK1 in the equatorial zone of phragmoplast and inhibition of the phragmoplast expansion by NPK1KW suggest the involvement of NPK1 in regulation of these processes because some of the processes described above occur in the equatorial zone. At the moment, we cannot clearly specify a process(es) in which NPK1 is involved because overexpression of NPK1KW may not necessarily lead to complete inhibition of the activation of NPK1 and result in leaky execution of the NPK1 function. However, it is worth noting that incomplete cell plates caused by the NPK1KW expression contain callose, which can be detected by aniline blue staining. Immunoelectron microscopic analysis has shown that callose deposition can only be seen after fusion of vesicles (Samuels et al. 1995). Thus, neither transport nor fusion of vesicles may be affected by the NPK1KW expression.

Therefore, it is likely that NPK1 acts to regulate outward redistribution of phragmoplast MTs. Further investigation of NPK1 functions will uncover detailed mechanisms for the cell-plate formation.

In addition to the incomplete cutokinesis, the aberrant nuclear separation was found on induction of the NPK1KW expression (Fig. 3-5). These observations suggest that NPK1 also functions in a process of the proper nuclear separation. It, however, has been not clear if NPK1 can directly or indirectly control such a process: NPK1 might regulate the cytokinesis, which might be required for the proper nuclear separation.

\section{Comparison with cytokinesis in plant} and animal cells

Cytokinesis in animal cells is achieved by contraction of the cell cortex (for review, see Field et al. 1999; Hales et al. 1999). Thus, animal and plant cells have developed apparently different strategies for cytokinesis. However, recent evidence that a syntaxin is required for cytokinesis in the nematode suggests that membrane-vesicle trafficking is involved in animal cytokinesis as well as in plant cytokinesis (Jantsch-Plunger and Glotzer 1999). In addition, the spindle midzone has been shown to play important roles in furrow ingression in animal systems (Adams et al. 1998; Raich et al. 1998; Field et al. 1999). In plants, the phragmoplast is formed in the spindle midzone. There are several reports suggesting that MAPK cascades might be involved in animal cytokinesis. Biochemical assay has shown that MAPKs are activated in cells progressing from $M$ into $G_{1}$ phase (Edelmann et al. 1996).

Active MAPKs and MAPKKs localize to the spindle midzone and midbody (Shapiro et al. 1998; Zecevic et al. 1998). Taken together, a MAPK cascade might regulate progression of cytokinesis in animal and plant cells by similar mechanisms involving membrane fusion and the action of midzonal MTs despite the opposite directions in progression.

In animals, two other families of protein kinases, the Polo-like family of protein kinases (PLKs) and the Aurora 1 kinase family, are required for cytokinesis (for review, see Glover et al. 1998; Bischoff and Plowman 1999, respectively). Structural similarities between NPK1 and either PLKs or the Aurora kinases are, however, not obvious. The systems involving NPK1 and these animal kinases control cytokinesis in plants and other organisms, respectively, but they might play different roles from in cytokinesis in respective organisms.

\section{Other functions of NPK1}

In the present paper, we have described the function of NPK1 only at the stage of cytokinesis. The NPK1 protein, however, is present from the $\mathrm{G}_{1} / \mathrm{S}$ boundary to the end of cytokinesis. Not only in early $M$ phase but in $S$ and $G_{2}$ phases, NPK1 localizes to the nucleus /data not shown), which is consistent with the presence of an amino acid sequence in NPK1 that is similar to that of the nuclear localization signal (see Fig. 1A). Thus, it is possible that NPK1 plays additional roles within the nucleus as well. Kovtun et al. $(1998,2000)$ reported that overexpression of the kinase domain of NPK1 or its Arabidopsis ortholog ANP1 results in suppression of auxininduced gene expression and in activation of oxidative stress signaling. Although it has to be clarified whether the truncated protein can transmit the same signals as the full-length protein does, their results and ours to- 
gether suggest that the NPK1 family might be multifunctional in plant cells, as proposed by Hirt (2000). Further studies of NPK1 might reveal how such diverse physiological roles are organized in vivo and facilitate an understanding of the network that modulates the balance between responses to environmental stimuli and control of cell proliferation in plants.

\section{Materials and methods}

\section{Plant materials and transformation}

Tobacco suspension-cultured cell line BY-2 was maintained at $26^{\circ} \mathrm{C}$ in the dark by weekly subculturing in modified Linsmaier and Skoog medium (Banno et al. 1993).

Tobacco plants, Nicotiana tabacum SR1, were grown on $\mathrm{Mu}-$ rashige and Skoog medium plates at $26^{\circ} \mathrm{C}$ under cycles of $16 \mathrm{~h}$ of light and $8 \mathrm{~h}$ of dark (Nakashima et al. 1998). Transgenic BY-2 cells and tobacco plants were generated by Agrobacterium-mediated transformation (Onouchi et al. 1995; Nakashima et al. 1998), in which LBA4404 strain was used.

\section{Synchronized culture}

For synchronization of the BY- 2 cell cycle from the $\mathrm{G}_{1} / \mathrm{S}$ boundary (Nagata et al. 1982), $20 \mathrm{~mL}$ of a 7-day-old cell culture were transferred to $95 \mathrm{~mL}$ of modified Linsmaier and Skoog medium that contained $5 \mathrm{mg} / \mathrm{L}$ aphidicolin (Wako Pure Chemicals, Tokyo, Japan). After cultured for $24 \mathrm{~h}$, cells were washed, resuspended in $95 \mathrm{~mL}$ of fresh medium and cultured further. For two-step synchronization from prometaphase (Kakimoto and Shibaoka 1988), propyzamide (Sumitomo Chemical, Osaka, Japan) was added (final concentration, $6 \mu \mathrm{M}$ ) to the cell culture 4 $\mathrm{h}$ after the removal of aphidicolin. After cultured for further $6 \mathrm{~h}$, cells were washed and cultured in fresh medium. At various time points after the drug removal, cells were harvested by centrifugation, frozen in liquid nitrogen and stored at $-80^{\circ} \mathrm{C}$ until use.

\section{DNA constructions}

The mutation at codon 109 (lysine to tryptophan) of NPK1coding region in pNPK1-6 was generated by PCR with mutagenic primers to yield pNPK1KW. Oligonucleotide for two copies of the HA epitope tag (MAYPYDVPDYASLGGHIYPYDVP DYAQISPW; the epitopes are underlined) was introduced into pNPK1-6 and pNPK1KW to generate HA-NPK1 and HANPK1KW in which the HA tags are fused just before the initiation codon of NPK1. Fusing NPK1- and NPK1KW-coding regions to the 3 ' end of the GFP-coding region derived from pTH-2 (Chiu et al. 1996) generated pGFP::NPK1 and pGFP::NPK1KW, respectively. DNAs coding HA-NPK1, HA-NPK1KW, GFP, GFP::NPK1, and GFP::NPK1KW were cloned into the pTA7001 vector (Aoyama and Chua 1997) to yield pTA71-HA-NPK1, pTA71-HA-NPK1KW, pTA71-GFP, pTA71-GFP::NPK1, and pTA71-GFP::NPK1KW, respectively.

\section{Antibody production and purification}

Antibody production was performed by Molecular Biology Laboratory (Nagoya, Japan). An oligopeptide, CTGNKEN VPSNINLPPKSR, that corresponds to amino acid residues of NPK1 at positions 557 to 574 was synthesized and conjugated to keyhole limpet hemocyanin. A rabbit was immunized by the conjugate, and a serum was obtained.
Antibodies (P557-2) specific to the peptide were purified from the serum as follows.

The oligopeptide $(0.5 \mu \mathrm{g})$ was immobilized to $0.15 \mathrm{~g}$ of FMPactivated Cellulofine (Seikagaku Kogyo, Tokyo, Japan). The serum $(3 \mathrm{~mL})$ was incubated with the peptide-immobilized resin overnight at room temperature. The resin was washed extensively with wash buffer containing $20 \mathrm{mM}$ Tris- $\mathrm{HCl}(\mathrm{pH} 7.5), 1$ $\mathrm{M} \mathrm{NaCl}, 1 \%$ Triton X-100, and then with Tris-buffered saline (TBS). Absorbed antibody molecules were eluted with $0.1 \mathrm{M}$ glycine- $\mathrm{HCl}(\mathrm{pH} 2.5)$ and neutralized immediately with $1 / 20$ volume of $1 \mathrm{M}$ Tris at $4^{\circ} \mathrm{C}$.

\section{Western blot analysis}

Frozen BY-2 cells were homogenized with $1 \times$ SDS sample buffer without bromophenol blue and boiled for $10 \mathrm{~min}$. Cell debris was removed by centrifugation. Protein concentration in extracts was measured by the Protein Assay Kit (Bio-Rad, Nagoya, Japan).

The extracts $(20 \mu \mathrm{g})$ were subjected to SDS-PAGE (10\% acrylamide, $0.67 \%$ bis-acrylamide). Proteins in the gels were transferred to Immobilon-P membrane (Millipore, Osaka, Japan) in transfer buffer (10 mM Tris, $192 \mathrm{mM}$ glycine, 20\% methanol). Membranes were blocked overnight at room temperature in 5\% skim milk dissolved in TBS containing $0.1 \%$ Tween-20 (TTBS) and washed two times in TTBS. Membranes were incubated with $0.5 \mu \mathrm{g} / \mathrm{mL}$ P557-2 antibodies in TBST containing $1 \%$ skim milk for $2 \mathrm{~h}$ at room temperature. Membranes were washed two times in TTBS and incubated for $2 \mathrm{~h}$ with a 1:1000 dilution of horseradish peroxidase-conjugated goat anti-rabbit IgG antibodies (Amersham Pharmacia, Tokyo, Japan). Membranes were washed two times in TTBS and two times in TBS. Signals were detected using ECL chemiluminescence kit (Amersham Pharmacia) on Kodak X-AR films.

\section{Phosphatase treatment}

Proteins in the extract prepared from BY-2 cells just after the release from the propyzamide block were precipitated with acetone and resuspended in the $\lambda$ phosphatase buffer (New England Biolabs [NEB], Beverly, MA) supplemented with or without $1 \mathrm{mM}$ sodium $o$-vanadate. $\lambda$ protein phosphatase (400 units; $\mathrm{NEB})$ were added to the suspensions containing $25 \mu \mathrm{g}$ of proteins and incubated at $37^{\circ} \mathrm{C}$ for $1 \mathrm{~h}$. After addition of an equal volume of $2 \times$ SDS sample buffer and boil, NPK1 proteins were detected by Western blot analysis with the P557-2 antibodies.

\section{Immunocomplex kinase assay}

Frozen cells were homogenized in TG250 buffer that contained 25 mM Tris- $\mathrm{HCl}$ (pH 7.5), 10 mM EDTA, 10 mM EGTA, 250 $\mathrm{mM} \mathrm{NaCl}, 10 \%$ glycerol, $0.1 \%$ Triton X-100, 1 mM dithiothreitol, $20 \mathrm{mM} \beta$-glycerophosphate, $1 \mathrm{mM}$ sodium $O$-vanadate, $0.3 \%$ bovine serum albumin (BSA), $1 \mathrm{mM}$ phenylmethanesulfonyl fluoride (PMSF), and $5 \mathrm{\mu g} / \mathrm{L}$ each of leupeptin, chymostatin, pepstatin A, and antipain. Extracts containing $200 \mu \mathrm{g}$ of proteins were diluted to $1 \mathrm{~mL}$ with $\mathrm{T} 150$ buffer (modified TG250 buffer with $150 \mathrm{mM} \mathrm{NaCl}$ instead of $250 \mathrm{mM}$ and no glycerol) and incubated with $0.5 \mu \mathrm{g}$ of the P557-2 antibodies on ice for $90 \mathrm{~min}$. Then, they were incubated with $10 \mu \mathrm{L}$ of $50 \%$ slurry of protein A-Sepharose (Amersham Pharmacia) at $4^{\circ} \mathrm{C}$ for $60 \mathrm{~min}$. The resin was washed four times in T150 buffer and twice in kinase buffer that contained $50 \mathrm{mM}$ Hepes- $\mathrm{KOH} / \mathrm{pH}$ 7.5), $20 \mathrm{mM} \mathrm{MgCl}_{2}, 5 \mathrm{mM}$ EGTA, $1 \mathrm{mM}$ dithiothreitol, $20 \mathrm{mM}$ $\beta$-glycerophosphate, and $1 \mathrm{mM}$ sodium $o$-vanadate. The resin 
was resuspended in a reaction cocktail $(20 \mu \mathrm{L})$ including $1 \mu \mathrm{g}$ of His-NQK1KW (produced in and purified from Escherichia coli), $50 \mu \mathrm{M}$ ATP, and $10 \mu \mathrm{Ci}$ of $\left[\gamma^{-32} \mathrm{P}\right]$ ATP in kinase buffer and incubated at $25^{\circ} \mathrm{C}$ for $30 \mathrm{~min}$. After addition of $20 \mu \mathrm{L}$ of $2 \times \mathrm{SDS}$ sample buffer and boil, samples were subjected to SDS-PAGE and radioactivity was visualized by an imaging analyzer BAS1800 (Fuji Film, Tokyo, Japan).

\section{Fluorescence microscopy}

Immunofluorescence analysis was performed by the procedure as essentially described previously (Yasuhara et al. 1993). BY-2 cells of $\sim 200 \mu \mathrm{L}$ cell volume that was synchronized in M phase were fixed with $3.7 \%$ formaldehyde in $50 \mathrm{mM}$ sodium phosphate buffer $(\mathrm{pH} 7.5)$ for $1 \mathrm{~h}$ in a microtube. For staining of G-WT and G-KW cell lines, fixation was performed by 10-min incubation with $2 \%$ paraformaldehyde in phosphate-buffered saline (PBS). Cell collection was performed by gravity-dependent sedimentation. Fixed cells were washed in $1.3 \mathrm{~mL}$ of PBS containing $0.02 \%$ Tween-20 (PBS-T) four times. Cell walls were briefly digested with $0.5 \%$ Cellulase Onozuka R-10, 0.05\% Pectolyase Y-23, $0.25 \mathrm{M}$ mannitol and $1 \mathrm{mM}$ PMSF (pH 5.5) at $30^{\circ} \mathrm{C}$ for $15 \mathrm{~min}$. After being washed in PBS-T two times, cells were permeabilized by 15 -min incubation with PBS-T containing $0.5 \%$ Triton X-100. After being washed in PBS-T twice and in PBS-T containing $1 \%$ BSA (PBS-TB) once, cells were incubated with $0.3 \mu \mathrm{g} / \mathrm{mL}$ anti-NPK1 antibodies (P557-2) and 1:2000 dilution of anti- $\alpha$-tubulin antibodies (DM1A, Sigma, St. Louis, $\mathrm{MO}$ ) in PBS-TB overnight at $4^{\circ} \mathrm{C}$. After being washed in PBS-T twice and in PBS-TB once, cells were incubated with 1:1000 dilution of rhodamine-conjugated anti-rabbit IgG antibodies (MBL) and 1:500 dilution of fluorescein isothiocyanate-conjugated anti-mouse IgG antibodies (MBL) at room temperature for $1 \mathrm{~h}$. Cells were washed in PBS-T containing $0.2 \mu \mathrm{g} / \mathrm{mL} \mathrm{4}, 6-$ diamidino-2-phenylindole (DAPI) once and in PBS-T twice. Cell suspension was mixed with equal volume of mount buffer $(20$ $\mathrm{mM} \mathrm{Na}_{2} \mathrm{HPO}_{4}, 150 \mathrm{mM} \mathrm{NaCl}$, and $50 \%$ glycerol) and stored at $4^{\circ} \mathrm{C}$ until observation.

For calcofluor staining, cells were fixed with $3.7 \%$ formaldehyde in $50 \mathrm{mM}$ sodium phosphate buffer $(\mathrm{pH} \mathrm{7.5)}$ for $1 \mathrm{~h}$ and stained with PBS-T containing $0.005 \%$ of calcofluor, $1 \mu \mathrm{g} / \mathrm{mL}$ propidium iodide (PI) and $10 \mu \mathrm{g} / \mathrm{mL}$ RNase A. For aniline blue staining, cells were fixed with $0.1 \%$ glutaraldehyde in $50 \mathrm{mM}$ sodium phosphate buffer $(\mathrm{pH} 7.5)$ for $1 \mathrm{~h}$ and washed four times in $2 \mathrm{mg} / \mathrm{mL} \mathrm{NaBH}$ and three times in $50 \mathrm{mM} \mathrm{Na}_{2} \mathrm{HPO}_{4}$. Cells were stained with $0.1 \%$ aniline blue, $1 \mu \mathrm{g} / \mathrm{mL}$ PI and $10 \mu \mathrm{g} / \mathrm{mL}$ RNase A in $50 \mathrm{mM} \mathrm{Na}_{2} \mathrm{HPO}_{4}$.

Fluorescence images were captured using a fluorescence microscope (Axioplan2, Carl Zeiss, Oberkochen, Germany) equipped with a cooled CCD camera system (Photometrics, Tucson, AZ). Pseudocoloring of the images and measurement of lengths of GFP signals and cell widths were performed using the software program IPLab (Scanalytics, Fairfax, VA).

\section{Light microscopy}

Orcein staining was performed to measure mitotic indices (proportions of cells bearing condensed chromosomes and oblong nuclei, corresponding to the early prophase to the late telophase, to whole populations) and to observe nuclei in multinucleate cells. BY-2 cells were stained with $1 \%$ orcein in $1: 1$ mixture of lactic acid and propionic acid. To observe nuclei in cotyledons, cotyledons were soaked in solution A $180 \%$ ethanol and $20 \%$ acetic acid) overnight and then stained with the same orcein solution for $4 \mathrm{~h}$. Tissues were washed in solution A for 4 $\mathrm{h}$ before observation. Normarski images were captured using a light microscope (Axiophot 2, Carl Zeiss) equipped with a highvision camera system (HDVTV-SYSTEM, Olympus, Tokyo, Japan).

\section{Acknowledgments}

We thank Stephan H. Howell and Steven E. Clark for critical reading of the manuscript; Takashi Aoyama and Nam-Hai Chua for providing pTA7001; Yasuo Niwa for providing pTH-2; Hiroki Yasuhara, Hiroharu Banno, and Keisuke Matsui for technical assistance and helpful discussion; and Sangho Jeong, Hirokazu Tanaka, and Michael J. Prigge for additional valuable comments on the manuscript. This work was supported in part by Grants-in-Aid for Scientific Research on Priority Areas (nos. 0678101-3 and 10182101-2) from the Japanese Ministry of Education, Science, Culture and Sports, and by a grant from the Research for the Future Program of the Japan Society for the Promotion of Science. R.N. was supported by Research Fellowships from the Japan Society for the Promotion of Science for Young Scientists.

The publication costs of this article were defrayed in part by payment of page charges. This article must therefore be hereby marked "advertisement" in accordance with 18 USC section 1734 solely to indicate this fact.

\section{References}

Acharya, U., Mallabiabarrena, A., Acharya, J.K., and Malhotra, V. 1998. Signaling via mitogen-activated protein kinase kinase (MEK1) is required for Golgi fragmentation during mitosis. Cell 92: 183-192.

Adams, R.R., Tavares, A.A., Salzberg, A., Bellen, H.J., and Glover, D.M. 1998. pavarotti encodes a kinesin-like protein required to organize the central spindle and contractile ring for cytokinesis. Genes \& Dev. 12: 1483-1494.

Aoyama, T. and Chua, N.-H. 1997. A glucocorticoid-mediated transcriptional induction system in transgenic plants. Plant J. 11: 605-612.

Asada, T., Kuriyama, R., and Shibaoka, H. 1997. TKRP125, a kinesin-related protein involved in the centrosome- independent organization of the cytokinetic apparatus in tobacco BY-2 cells. J. Cell Sci. 110: 179-189.

Banno, H., Hirano, K., Nakamura, T., Irie, K., Nomoto, S., Matsumoto, K., and Machida, Y. 1993. NPK1, a tobacco gene that encodes a protein with a domain homologous to yeast BCK1, STE11, and Byr2 protein kinases. Mol. Cell. Biol. 13: 47454752.

Bischoff, J.R. and Plowman, G.D. 1999. The Aurora/Ipllp kinase family: regulators of chromosome segregation and cytokinesis. Trends Cell Biol. 9: 454-459.

Bögre, L., Calderini, O., Binarova, P., Mattauch, M., Till, S., Kiegerl, S., Jonak, C., Pollaschek, C., Barker, P., Huskisson, N.S., et al. 1999. A MAP kinase is activated late in plant mitosis and becomes localized to the plane of cell division. Plant Cell 11: 101-113.

Bowser, J. and Reddy, A.S. 1997. Localization of a kinesin-like calmodulin-binding protein in dividing cells of Arabidopsis and tobacco. Plant $J$. 12: 1429-1437.

Calderini, O., Bögre, L., Vicente, O., Binarova, P., Heberle-Bors, E., and Wilson, C. 1998. A cell cycle regulated MAP kinase with a possible role in cytokinesis in tobacco cells. J. Cell Sci. 111: 3091-3100.

Chiu, W., Niwa, Y., Zeng, W., Hirano, T., Kobayashi, H., and Sheen, J. 1996. Engineered GFP as a vital reporter in plants. 
Curr. Biol. 6: 325-330.

Edelmann, H.M., Kühne, C., Petritsch, C., and Ballou, L.M. 1996. Cell cycle regulation of p70 S6 kinase and p42/p44 mitogen-activated protein kinases in Swiss mouse 3 T3 fibroblasts. J. Biol. Chem. 271: 963-971.

Feiler, H.S., Desprez, T., Santoni, V., Kronenberger, J., Caboche, M., and Traas, J. 1995. The higher plant Arabidopsis thaliana encodes a functional CDC48 homologue which is highly expressed in dividing and expanding cells. EMBO I. 14: 56265637.

Field, C., Li, R., and Oegema, K. 1999. Cytokinesis in eukaryotes: A mechanistic comparison. Curr. Opin. Cell Biol. 11: $68-80$.

Garrington, T.P. and Johnson, G.L. 1999. Organization and regulation of mitogen-activated protein kinase signaling pathways. Curr. Opin. Cell Biol. 11: 211-218.

Glover, D.M., Hagan, I.M., and Tavares, A.A. 1998. Polo-like kinases: A team that plays throughout mitosis. Genes \& Dev. 12: 3777-3787.

Graves, L.M., Guy, H.I., Kozlowski, P., Huang, M., Lazarowski, E., Pope, R.M., Collins, M.A., Dahlstrand, E.N., Earp III, H.S., and Evans, D.R. 2000. Regulation of carbamoyl phosphate synthetase by MAP kinase. Nature 403: 328-332.

$\mathrm{Gu}, \mathrm{X}$. and Verma, D.P.S. 1996. Phragmoplastin, a dynamin-like protein associated with cell plate formation in plants. $E M B O$ J. 15: 695-704.

Gunning, B.E.S. 1982. The cytokinetic apparatus: its development and spatial regulation. In The Cytoskeleton in Plant Growth and Development (ed. C.W. Lloyd), pp. 229-292. Academic Press, London.

Hales, K.G., Bi, E., Wu, J.Q., Adam, J.C., Yu, I.C., and Pringle, J.R. 1999. Cytokinesis: An emerging unified theory for eukaryotes? Curr. Opin. Cell Biol. 11: 717-725.

Heese, M., Mayer, U., and Jürgens, G. 1998. Cytokinesis in flowering plants: Cellular process and developmental integration. Curr. Opin. Plant Biol. 1: 486-491.

Hirt, H. 2000. Connecting oxidative stress, auxin, and cell cycle regulation through a plant mitogen-activated protein kinase pathway. Proc. Natl. Acad. Sci. 97: 2405-2407.

Jantsch-Plunger, V. and Glotzer, M. 1999. Depletion of syntaxins in the early Caenorhabditis elegans embryo reveals a role for membrane fusion events in cytokinesis. Curr. Biol. 9: $738-745$.

Kakimoto, T. and Shibaoka, H. 1988. Cytoskeletal ultrastructure of phragmoplast-nuclei complexes isolated from cultured tobacco cells. Protoplasma (suppl.) 2: 95-103.

Kang, H.G., Fang, Y., and Singh, K.B. 1999. A glucocorticoidinducible transcription system causes severe growth defects in Arabidopsis and induces defense-related genes. Plant $J$. 20: 127-133.

Kovtun, Y., Chiu, W.L., Zeng, W., and Sheen, J. 1998. Suppression of auxin signal transduction by a MAPK cascade in higher plants. Nature 395: 716-720.

Kovtun, Y., Chiu, W.L., Tena, G., and Sheen, J. 2000. Functional analysis of oxidative stress-activated mitogen-activated protein kinase cascade in plants. Proc. Natl. Acad. Sci. 97: 2940-2945.

Lauber, M.H., Waizenegger, I., Steinmann, T., Schwarz, H., Mayer, U., Hwang, I., Lukowitz, W., and Jürgens, G. 1997. The Arabidopsis KNOLLE protein is a cytokinesis-specific syntaxin. J. Cell Biol. 139: 1485-1493.

Lee, F.S., Hagler, J., Chen, Z.J., and Maniatis, T. 1997. Activation of the IкB $\alpha$ kinase complex by MEKK1, a kinase of the JNK pathway. Cell 88: 213-222.

Lee, Y.R. and Liu, B. 2000. Identification of a phragmoplastassociated kinesin-related protein in higher plants. Curr.
Biol. 10: $797-800$.

Liu, B., Cyr, R.J., and Palevitz, B.A. 1996. A kinesin-like protein, KatAp, in the cells of Arabidopsis and other plants. Plant Cell 8: 119-132.

Lukowitz, W., Mayer, U., and Jürgens, G. 1996. Cytokinesis in the Arabidopsis embryo involves the syntaxin-related KNOLLE gene product. Cell 84: 61-71.

Minshull, J., Sun, H., Tonks, N.K., and Murray, A.W. 1994. A MAP kinase-dependent spindle assembly checkpoint in Xenopus egg extracts. Cell 79: 475-486.

Mironov, V., De Veylder, L., Van Montagu, M., and Inze, D. 1999. Cyclin-dependent kinases and cell division in plantsthe nexus. Plant Cell 11: 509-522.

Nagata, T., Okada, K., and Takebe, I. 1982. Mitotic protoplasts and their infection with tobacco mosaic virus RNA encapsulated in liposome. Plant Cell Rep. 1: 250-252.

Nakashima, M., Hirano, K., Nakashima, S., Banno, H., Nishihama, R., and Machida, Y. 1998. The expression pattern of the gene for NPK1 protein kinase related to mitogen-activated protein kinase kinase kinase (MAPKKK) in a tobacco plant: correlation with cell proliferation. Plant Cell Physiol. 39: 690-700.

Ninomiya-Tsuji, J., Kishimoto, K., Hiyama, A., Inoue, J., Cao, Z., and Matsumoto, K. 1999. The kinase TAK1 can activate the NIK-IKB as well as the MAP kinase cascade in the IL-1 signalling pathway. Nature 398: 252-256.

Nishihama, R., Banno, H., Kawahara, E., Irie, K., and Machida, Y. 1997. Possible involvement of differential splicing in regulation of the activity of Arabidopsis ANP1 that is related to mitogen-activated protein kinase kinase kinases (MAPKKKs). Plant T. 12: 39-48.

Nishihama, R. and Machida, Y. 2000. The MAP kinase cascade that includes MAPKKK-related protein kinase NPK1 controls a mitotic process in plant cells. Results Probl. Cell Differ. 27: 119-130.

Onouchi, H., Nishihama, R., Kudo, M., Machida, Y., and Machida, C. 1995. Visualization of site-specific recombination catalyzed by a recombinase from Zygosaccharomyces rouxii in Arabidopsis thaliana. Mol. Gen. Genet. 247: 653-660.

Pages, G., Lenormand, P., L'Allemain, G., Chambard, J.C., Meloche, S., and Pouyssegur, J. 1993. Mitogen-activated protein kinases $\mathrm{p} 42 \mathrm{mapk}$ and $\mathrm{p} 44 \mathrm{mapk}$ are required for fibroblast proliferation. Proc. Nat1. Acad. Sci. 90: 8319-8323.

Posas, F. and Saito, H. 1998. Activation of the yeast SSK2 MAP kinase kinase kinase by the SSK1 two-component response regulator. EMBO J. 17: 1385-1394.

Raich, W.B., Moran, A.N., Rothman, J.H., and Hardin, J. 1998. Cytokinesis and midzone microtubule organization in Caenorhabditis elegans require the kinesin-like protein ZEN-4. Mol. Biol. Cell 9: 2037-2049.

Robinson, M.J. and Cobb, M.H. 1997. Mitogen-activated protein kinase pathways. Curr. Opin. Cell Biol. 9: 180-186.

Sakurai, H., Miyoshi, H., Toriumi, W., and Sugita, T. 1999. Functional interactions of transforming growth factor $\beta$-activated kinase 1 with ІкB kinases to stimulate NF-кB activation. J. Biol. Chem. 274: 10641-10648.

Sakurai, H., Miyoshi, H., Mizukami, J., and Sugita, T. 2000. Phosphorylation-dependent activation of TAK1 mitogen-activated protein kinase kinase kinase by TAB1. FEBS Lett. 474: $141-145$.

Samuels, A.L., Giddings, Jr., T.H., and Staehelin, L.A. 1995. Cytokinesis in tobacco BY-2 and root tip cells: A new model of cell plate formation in higher plants. J. Cell Biol. 130: 13451357.

Shapiro, P.S., Vaisberg, E., Hunt, A.J., Tolwinski, N.S., Whalen, A.M., McIntosh, J.R., and Ahn, N.G. 1998. Activation of the 
MKK/ERK pathway during somatic cell mitosis: direct interactions of active ERK with kinetochores and regulation of the mitotic 3F3/2 phosphoantigen. J. Cell Biol. 142: 15331545.

Smith, L.G. 1999. Divide and conquer: cytokinesis in plant cells. Curr. Opin. Plant Biol. 2: 447-453.

Staehelin, L.A. and Hepler, P.K. 1996. Cytokinesis in higher plants. Cell 84: 821-824.

Takekawa, M. and Saito, H. 1998. A family of stress-inducible GADD45-like proteins mediate activation of the stress-responsive MTK1/MEKK4 MAPKKK. Cell 95: 521-530.

Takenaka, K., Moriguchi, T., and Nishida, E. 1998. Activation of the protein kinase p38 in the spindle assembly checkpoint and mitotic arrest. Science 280: 599-602.

Wright, J.H., Munar, E., Jameson, D.R., Andreassen, P.R., Margolis, R.L., Seger, R., and Krebs, E.G. 1999. Mitogen-activated protein kinase kinase activity is required for the G2/M transition of the cell cycle in mammalian fibroblasts. Proc. Natl. Acad. Sci. 96: 11335-11340.

Yasuhara, H., Sonobe, S., and Shibaoka, H. 1993. Effects of taxol on the development of the cell plate and of the phragmoplast in tobacco BY-2 cells. Plant Cell Physiol. 34: 21-29.

Yasuhara, H. and Shibaoka, H. 2000. Inhibition of cell-plate formation by brefeldin A inhibited the depolymerization of microtubules in the central region of the phragmoplast. Plant Cell Physiol. 41: 300-310.

Zecevic, M., Catling, A.D., Eblen, S.T., Renzi, L., Hittle, J.C., Yen, T.J., Gorbsky, G.J., and Weber, M.J. 1998. Active MAP kinase in mitosis: Localization at kinetochores and association with the motor protein CENP-E. J. Cell Biol. 142: 15471558.

Zuo, J., Niu, Q.W., Nishizawa, N., Wu, Y., Kost, B., and Chua, N.-H. 2000. KORRIGAN, an Arabidopsis endo-1,4- $\beta-$ glucanase, localizes to the cell plate by polarized targeting and is essential for cytokinesis. Plant Cell 12: 1137-1152. 


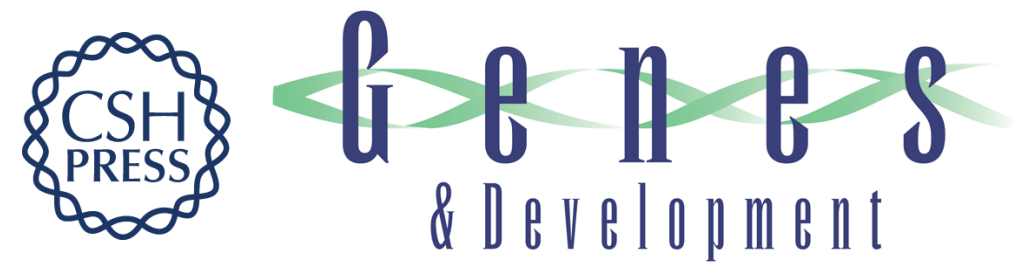

\section{The NPK1 mitogen-activated protein kinase kinase kinase is a regulator of cell-plate formation in plant cytokinesis}

Ryuichi Nishihama, Masaki Ishikawa, Satoshi Araki, et al.

Genes Dev. 2001, 15:

Access the most recent version at doi:10.1101/gad.863701

References This article cites 52 articles, 22 of which can be accessed free at: http://genesdev.cshlp.org/content/15/3/352.full.html\#ref-list-1

License

Email Alerting

Receive free email alerts when new articles cite this article - sign up in the box at the top Service right corner of the article or click here.

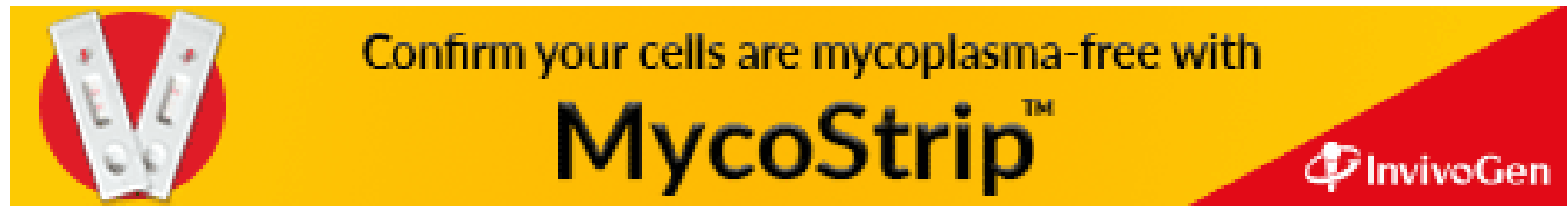

